Chem. Pharm. Bull.

31(12)4300-4305(1983)

\title{
Reaction of Diketene-Acetone Adduct with Enamines, Ketene Acetals, Vinyl Ethers, and $\beta$-Diketones
}

\author{
Masayuki Sato, ${ }^{*}$ Hiromichi Ogasawara, Keiko Kato, \\ Masako SAKai, and Tetsuzo Kato \\ Pharmaceutical Institute, Tohoku University, \\ Aobayama, Sendai 980 , Japan
}

(Received April 20, 1983)

\begin{abstract}
Diketene-acetone adduct (1) generates acetylketene (2) under heating. In order to compare the reactivity of $\mathbf{2}$ with that of diketene, the reaction of $\mathbf{1}$ with electron-rich olefins was investigated.

On heating with 1 , primary enamines (3a- d) produced the corresponding 3-substituted 2,6dimethyl-4(1H)-pyridones $(\mathbf{4 a - d})$, while the tertiary enamine $3 \mathbf{e}$ gave the 4-pyrone derivative (7). The reaction of 1 with ketene acetals (8) gave the 2,2-diethoxy-2,3-dihydro-4-pyrone derivatives (9). The vinyl ether derivatives 13 similarly reacted with 1 to give the 4-pyrone derivative 15 or 16 as the major product. The result shows that both diketene and 2 react with electron-rich olefins in a similar manner.
\end{abstract}

Keywords_- diketene; acetylketene; diketene-acetone adduct; enamine; ketene acetal; vinyl ether; 1,3-dioxin-4-one; 4-pyridone; 4-pyrone; cycloaddition

Diketene-acetone adduct $(1)^{1)}$ shows a remarkable reactivity under heating. The adduct 1 reacts with amines, alcohols, ${ }^{1)}$ and amides ${ }^{2)}$ to produce acetoacetylated compounds, and it also reacts with compounds having a $\mathrm{C}=\mathrm{N}$ or $\mathrm{C} \equiv \mathrm{N}$ group to produce 1,3-oxazin-4-ones. ${ }^{3)}$ Such a reactivity, which is analogous to that of diketene ${ }^{4)}$ itself, can be rationalized in terms of thermal fragmentation of $\mathbf{1}$ to acetylketene (2). ${ }^{3 a)}$ We recently obtained evidence that strongly supports the involvement of an intermediary acetylketene. ${ }^{3 d)}$

In order to compare acetylketene with diketene in terms of reactivity, we studied the reaction of 1 with enamines, ketene acetals, vinyl ethers, and $\beta$-diketones.

\section{Reaction with Enamines}

On treatment with diketene, tertiary enamines produce 4-pyrones,${ }^{5)}$ while primary and secondary enamines usually produce 4 -pyridones. ${ }^{6)}$

When 1 was heated with primary enamines $(3 \mathbf{a}-\mathbf{d}), 4$-pyridones $(\mathbf{4 a}-\mathbf{d})$ were obtained. The enamine $3 c$ gave the $N$-acylated product $5 c$ as a by-product. Compound 4 is presumably formed via the $C$-acetoacetylated intermediate $\mathbf{6}$. The tertiary enamine $\mathbf{3 e}$, on treatment with 1 , gave the chromone derivative 7 and $N$-acetoacetylmorpholine.

The products 4,5 , and 7 are also formed by the use of diketene and the yields are comparable to that from the adduct $\mathbf{1}$. Therefore, it can be concluded that acetylketene and diketene both show similar reactivity towards enamines.

\section{Reaction with Ketene Acetals}

Previously, we have reported that diketene adds to ketene acetals ( $8 \mathbf{a}$ and $\mathbf{8 b}$ ) to give 2,2diethoxy-2,3-dihydro-4-pyrones $(\mathbf{9 a}$ and $\mathbf{9 b}){ }^{7}{ }^{7}$ Thus, we tried the reaction of adduct $\mathbf{1}$ with ketene acetals under heating, and obtained the same products 9 in better yields $(51-70 \%)$. In addition, the less reactive acetal $8 \mathrm{c}$ also afforded the product $9 \mathrm{c}$ which was not obtained from diketene. When the reaction was conducted without any solvent, the acetal 8a gave the 
<smiles>C=C1CC(=O)O1</smiles><smiles>[R]/C=C(/C)N</smiles>

3

3a $: \mathrm{R}=\mathrm{COMe}$

4<smiles>CC1=CC(=O)OC(C)(C)O1</smiles>

1<smiles>CC(=O)C=C=O</smiles>

3b : $\mathrm{R}=\mathrm{CO}_{2} \mathrm{Et}$

3c : $\mathrm{R}=\mathrm{CN}$

3d $: \mathrm{R}=\mathrm{COPh}$<smiles>Cc1cc(=O)c2c(o1)CCCC2</smiles>

Chart 1

benzene derivative 10 as a by-product.

The most reasonable pathway to the products is shown in Chart 2. Though cycloaddition of acetylketene $\mathbf{2}$ with $\mathbf{8}$ to give $\mathbf{9}$ can be explained either by a stepwise mechanism which involves the intermediate $\mathbf{1 1}$ or by a concerted mechanism, the former is better able to explain the formation of 10. Namely, further addition of $\mathbf{8 a}$ to the intermediate 11 gives the intermediate 12, which produces $\mathbf{1 0}$ with elimination of ethanol.

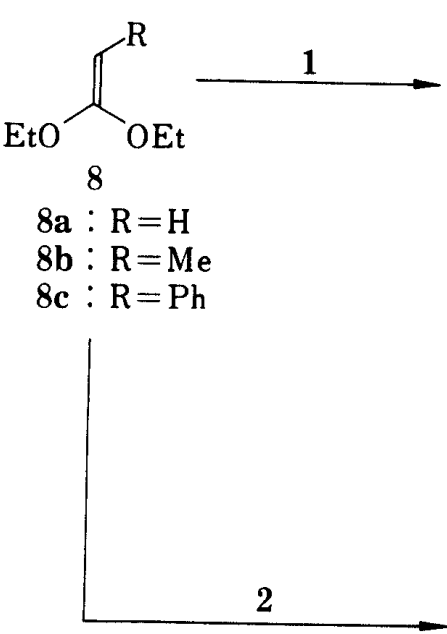<smiles>[R]C1C(=O)C=C(C)OC1(OCC)OCC</smiles><smiles>CCOc1cc(O)c(C(C)=O)c(OCC)c1</smiles><smiles>[Te]</smiles>

$$
1
$$<smiles>[R]C(C(=O)OCC)[C@H](OCC)C(=O)CC(C)=O</smiles>

11<smiles>[R]C(N)=C(C)C(=O)CC(C)=O</smiles>

6 


\section{Reaction with Vinyl Ethers}

Next, we examined the reaction of 1 with vinyl ethers. When $\alpha$-ethoxystyrene (13a) was heated with two equivalents of 1, 2-methyl-6-phenyl-4-pyrone (15a) was obtained in $30 \%$ yield. On similar treatment, butyl vinyl ether (13b) gave 2-methyl-4-pyrone (15b) together with a small amount of the 2,6-dimethyl-4-pyrone derivative (16b), while 3,4-dihydropyran (13c) gave only the 2,6-dimethyl-4-pyrone (16c) in $42 \%$ yield.

When the reaction of 13a with 1 was conducted under milder conditions, the dihydropyrone derivative (14a) was obtained in low yield together with $\mathbf{1 5 a}$.

The 1,4-cycloadduct that corresponds to $\mathbf{1 4 a}$ is probably formed in every case. However, the cycloadduct (14) is transformed to 15 with the elimination of the alcohol during the reaction. Addition of acetylketene $\mathbf{2}$ to a zwitterionic intermediate $\mathbf{1 7}$ would give the tetraketone 18, which spontaneously cyclized to $\mathbf{1 6 .}$

Reaction of diketene with vinyl ethers has not been reported. Reaction of 13a with diketene even in the presence of a catalyst such as triethylamine or $p$-toluenesulfonic acid resulted in the recovery of the starting material 13a.<smiles>[R]C=C([R])O[R]</smiles>

13

13a $: \mathrm{R}^{1}=\mathrm{H}, \mathrm{R}^{2}=\mathrm{Ph}, \mathrm{R}^{3}=\mathrm{Et}$

$13 \mathbf{b}: \mathrm{R}^{1}=\mathrm{H}, \mathrm{R}^{2}=\mathrm{H}, \mathrm{R}^{3}=\mathrm{Bu}$

13c : $\mathrm{R}^{1}=\left(\mathrm{CH}_{2}\right)_{3}=\mathrm{R}^{3}, \mathrm{R}^{2}=\mathrm{H}$
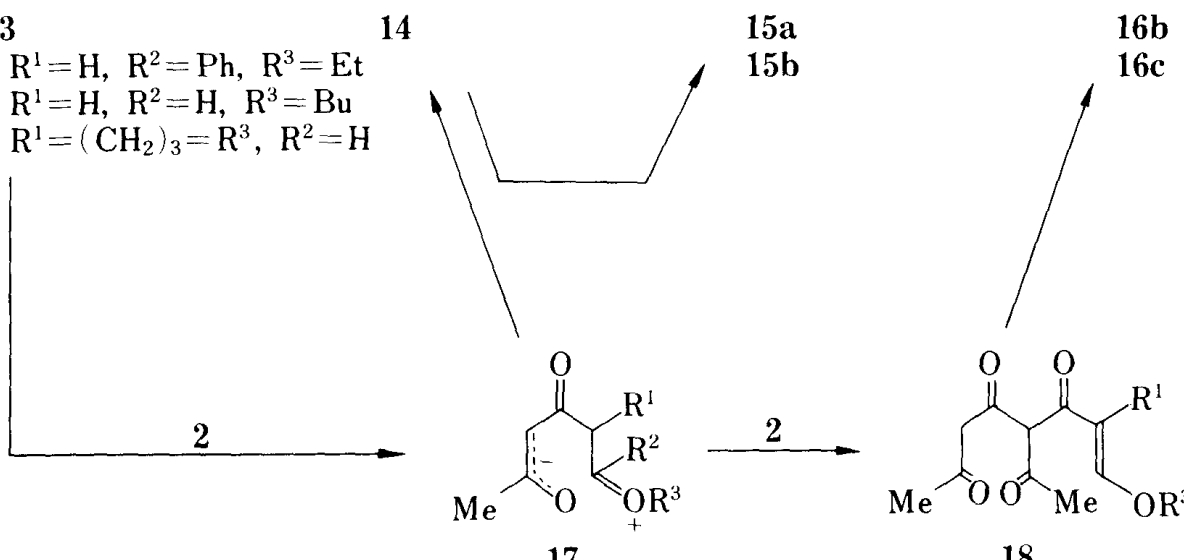

Chart 3<smiles>[R]C(=O)CC(C)=O</smiles>

$19 a, b$

$19 \mathrm{a}: \mathrm{R}=\mathrm{Me}$

$19 b: \mathrm{R}=\mathrm{Ph}$

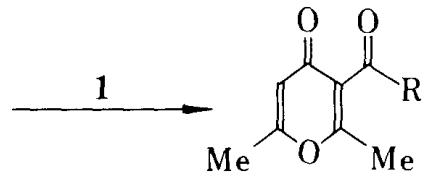

$20 \mathrm{a}, \mathrm{b}$<smiles>CC(=O)CC1([Al])OC(=O)C=C(C)O1</smiles>

21<smiles>CC1=CC(=O)OC2(CCCC2)O1</smiles>

22<smiles>[R]C1=C([R])C(=O)OC(C)(C)O1</smiles>

23<smiles>[R]C=C1OC(=O)C1[R]</smiles>

24

Chart 4 


\section{Reaction with $\beta$-Diketones}

In the presence of a basic or acidic catalyst, diketene reacts with $\beta$-diketones to yield the 4-pyrone derivative. ${ }^{8)}$ In connection with this fact, the reaction of 1 with $\beta$-diketone was studied.

The reaction of 1 with acetylacetone (19a) and benzoylacetone (19b) proceeded without any catalyst to yield the corresponding 4-pyrones (20a and $\mathbf{2 0 b}$ ). The yield was slightly better than that from diketene. In contrast to the reaction of diketene, the use of catalysts such as triethylamine and $p$-toluenesulfonic acid resulted in a significant decrease of the yield.

The reaction of 19a with 1 afforded the 1,3-dioxin-4(2H)-one derivative (21) as a byproduct. A similar compound (22) was obtained from cyclohexanone in a good yield on treatment with 1. Compounds 21 and 22 are the 1,4-cycloadducts of the ketones with acetylketene.

\section{Conclusion}

Most reactions of diketene fall into the category of addition reactions to produce acetoacetyl compounds or heterocyclic compounds. ${ }^{4)}$ The results of this work and our previous studies on the adduct 1 show that 1 is equally useful for preparation of such compounds, and 1 often gives better results due to the higher reactivity of the intermediary acetylketene. Moreover, the results suggest that the dioxinone $\mathbf{2 3}$ may react analogously to the mixed diketene $\mathbf{2 4}$, which is not easily accessible. ${ }^{9}$

\section{Experimental}

All melting and boiling points are uncorrected. Infrared (IR) spectra were measured with a JASCO A-102 spectrometer. Nuclear magnetic resonance (NMR) spectra were measured on a JEOL JNM-PMX 60 spectrometer and data are reported as $\delta$ values (ppm) relative to tetramethylsilane as an internal standard. Mass spectra (MS) were obtained on a Hitachi M-52G mass spectrometer. Unless otherwise noted, all known compounds were identified by comparison of the IR spectra with those of authentic samples prepared according to the literature.

Reaction of Adduct 1 with Primary Enamines: General Procedure-_-Enamines 3a, ${ }^{10)} 3 b,{ }^{11)} 3 c,{ }^{12)}$ and $3 d^{13)}$ were prepared according to the literature. A mixture of $\mathbf{1}^{1)}(40 \mathrm{mmol})$ and $3(20 \mathrm{mmol})$ was heated in a flask, directly attached to a tube of calcium chloride, at 120-130 C (bath temperature) for $1 \mathrm{~h}$. Products were isolated in the following manner.

3-Acetyl-2,6-dimethyl-4(1H)-pyridone (4a)_Ether $(10 \mathrm{ml})$ was added to the reaction mixture. Crystals were collected by suction and recrystallized from ethanol to give $4 \mathrm{a}$ as needles of $\mathrm{mp} 234-235 \mathrm{C}$ (lit. ${ }^{6 b}$ mp $240^{\circ} \mathrm{C}$ ). Yield, $1.47 \mathrm{~g}(44 \%)$.

Ethyl 2,6-Dimethyl-4(1 H)-pyridone-3-carboxylate (4b) — The crude crystals obtained in the above manner were recrystallized from acetone to give $4 \mathbf{b}$ as needles of $\mathrm{mp} 1688^{\circ} \mathrm{C}$ (lit. ${ }^{6 b} \mathrm{mp} 167 \mathrm{C}$ ). Yield, $1.56 \mathrm{~g}(40 \%)$.

3-Cyano-2,6-dimethyl-4(1 H)-pyridone (4c) and 3-acetoacetamidocrotononitrile (5c)-Ethyl acetate (10 ml) was added to the reaction mixture. Crystals were collected by suction and recrystallized from ethanol to give $\mathbf{4 c}$ as prisms of $\mathrm{mp} \mathrm{104-106} \mathrm{C} \mathrm{(lit.}{ }^{6 \mathrm{~b})} \mathrm{mp} 105-107^{\circ} \mathrm{C}$ ). Yield, $1.94 \mathrm{~g}\left(66^{\circ} \%\right.$ ). The ethyl acetate-soluble fraction was concentrated and crystallized from ether. Recrystallization from benzene gave $5 \mathrm{c}$ as plates of $\mathrm{mp} 78-81{ }^{\circ} \mathrm{C}$ (lit. ${ }^{6 b}$ mp $85^{\circ} \mathrm{C}$ ). Yield, $0.66 \mathrm{~g}(20 \%)$.

3-Benzoyl-2,6-dimethyl-4(1H)-pyridone $(4 \mathrm{~d})$ - Ether $(10 \mathrm{ml})$ was added to the reaction mixture. Crystals were collected by suction and recrystallized from ethanol to give $4 \mathbf{d}$ as needles of $\mathrm{mp} 290 \mathrm{C}$ (dec.) [lit. ${ }^{6 a)} \mathrm{mp} 301{ }^{\circ} \mathrm{C}$ (dec.)]. Yield, $1.0 \mathrm{~g}(22 \%)$.

2-Methyl-5,6,7,8-tetrahydrochromone (7)-A mixture of $1(2.84 \mathrm{~g})$ and $3 \mathrm{e}^{14)}(1.67 \mathrm{~g})$ was heated at $120-130^{\circ} \mathrm{C}$ for $90 \mathrm{~min}$. The reaction mixture was dissolved.in chloroform $(150 \mathrm{ml})$ and extracted with $150 \mathrm{ml}$ of $10 \%$ sodium hydroxide solution which was saturated with sodium chloride. The organic layer was dried over sodium sulfate and then concentrated. The residue on recrystallization from hexane gave 7 as prisms of $\mathrm{mp} 95-96{ }^{\circ} \mathrm{C}$ (lit. ${ }^{6 a)} \mathrm{mp} 97$ $98 \mathrm{C})$. Yield, $1.16 \mathrm{~g}(71 \%)$. The above aqueous layer was neutralized with dil. hydrochloric acid and extracted with chloroform. Concentration of the organic layer gave an oil, which was distilled to give $N$-acetoacetylmorpholine as an oil of bp $98-103 \mathrm{C}(0.6 \mathrm{mmHg})$. Yield, $0.68 \mathrm{~g}(40 \%)$.

Reaction of 1 with Ketene Diethylacetal (8a)_a) A mixture of $1(2.13 \mathrm{~g}), \mathbf{8 a}^{15)}(1.75 \mathrm{~g})$, and dry toluene $(16 \mathrm{ml})$ was heated under reflux for $40 \mathrm{~min}$. Distillation of the mixture gave 2,2-diethoxy-2,3-dihydro-6-methyl-4-pyrone (9a) 
as an oil of bp $80-83^{\circ} \mathrm{C}(0.3 \mathrm{mmHg})\left[\left[_{i t}{ }^{7)}\right.\right.$ bp $\left.83-84^{\circ} \mathrm{C}(3 \mathrm{mmHg})\right]$. Yield, $2.1 \mathrm{~g}(70 \%)$.

b) A mixture of $1(6.15 \mathrm{~g})$ and $8 \mathrm{a}(2.52 \mathrm{~g})$ was heated at $110^{\circ} \mathrm{C}$ for $30 \mathrm{~min}$. Distillation of the mixture gave $1.55 \mathrm{~g}$ $(28 \%)$ of $9 \mathrm{a}$ and a residue $(1.4 \mathrm{~g})$. The residue was purified by silica gel column chromatography using ether as an eluent to give 2,4-diethoxy-6-hydroxyacetophenone (10) as needles of mp $83^{\circ} \mathrm{C}\left(\right.$ lit. $\left.^{16)} \mathrm{mp} 85^{\circ} \mathrm{C}\right)$. Yield, $0.53 \mathrm{~g}\left(22^{\circ}\right)$.

Reaction of 1 with Methylketene Diethylacetal (8b)-A mixture of $1(1.42 \mathrm{~g}), 8 \mathbf{b}^{17)}(1.34 \mathrm{~g})$, and dry toluene $(10 \mathrm{ml})$ was heated under reflux for $30 \mathrm{~min}$. Purification by distillation gave 2,2-diethoxy-2,3-dihydro-3,6-dimethyl-4pyrone (9b) as an oil of bp $70^{\circ} \mathrm{C}(0.15 \mathrm{mmHg})$ [lit. ${ }^{7)}$ bp $\left.95-96^{\circ} \mathrm{C}(3 \mathrm{~mm} \mathrm{Hg})\right]$. Yield, $1.29 \mathrm{~g}\left(60^{\circ}\right)$.

Reaction of 1 with Phenylketene Diethylacetal (8c)—A mixture of $1(1.42 \mathrm{~g}), 8 \mathrm{c}^{18)}(1.96 \mathrm{~g})$, and dry toluene $(10 \mathrm{ml})$ was heated under reflux for $30 \mathrm{~min}$. The reaction mixture was chromatographed on a silica gel $(60 \mathrm{~g})$ column. Elution with a mixture of hexane-ether (1:1) gave 2,2-diethoxy-2,3-dihydro-6-methyl-3-phenyl-4-pyrone (9c) as prisms of mp 98-101 $\mathrm{C}$ (from ether-hexane). Yield, $1.4 \mathrm{~g}\left(51 \%\right.$ ). Anal. Calcd for $\mathrm{C}_{16} \mathrm{H}_{24} \mathrm{O}_{4}: \mathrm{C}, 69.54 ; \mathrm{H}, 7.30$. Found: $\mathrm{C}, 69.24 ; \mathrm{H}, 7.58$. IR $\left(\mathrm{CHCl}_{3}\right): 1670(\mathrm{C}=\mathrm{O}), 1630(\mathrm{C}=\mathrm{C}) \mathrm{cm}^{-1} \cdot{ }^{1} \mathrm{H}-\mathrm{NMR}\left(\mathrm{CDCl}_{3}\right) \delta: 0.87,1.00($ each $3 \mathrm{H}, \mathrm{t}$, $\left.J=7 \mathrm{~Hz}, 2 \times \mathrm{OCH}_{2} \mathrm{CH}_{3}\right), 1.97\left(3 \mathrm{H}, \mathrm{s}, \mathrm{C}_{6}-\mathrm{Me}\right), 3.30-4.00\left(4 \mathrm{H}, \mathrm{m}, 2 \times \mathrm{OCH}_{2} \mathrm{CH}_{3}\right), 3.93\left(1 \mathrm{H}, \mathrm{s}, \mathrm{C}_{3}-\mathrm{H}\right), 5.20(1 \mathrm{H}, \mathrm{s}$, $\left.\mathrm{C}_{5}-\mathrm{H}\right), 7.15(5 \mathrm{H}, \mathrm{s}, \mathrm{Ph})$.

Reaction of 1 with $\alpha$-Ethoxystyrene (13a) _ - a) A mixture of $1(2.84 \mathrm{~g})$ and $13 \mathrm{a}^{19)}(1.48 \mathrm{~g})$ was heated at $130^{\circ} \mathrm{C}$ for $5 \mathrm{~h}$. The reaction mixture was chromatographed on a silica gel $(40 \mathrm{~g})$ column. Elution with hexane-ethyl acetate (1:1) gave unreacted 13a. Elution with ethyl acetate gave crude 15a. Recrystallization from ether-hexane gave needles of $\mathrm{mp} 86-87^{\circ} \mathrm{C}\left(\right.$ lit. $\left.^{20)} \mathrm{mp} 87-88^{\circ} \mathrm{C}\right)$. Yield, $0.5 \mathrm{~g}(30 \%)$.

b) A mixture of $1(2.13 \mathrm{~g})$ and 13a $(4.44 \mathrm{~g})$ was heated at $120^{\circ} \mathrm{C}$ for $2 \mathrm{~h}$. Excess 13a was distilled off under reduced pressure. The residue was purified by medium pressure column chromatography (Kieselgel $\mathrm{H} 60, \mathrm{Merck}$ ). Elution with hexane-ethyl acetate (1:1) gave 2-ethoxy-2,3-dihydro-6-methyl-4-pyrone (14a) as an oil. ${ }^{21)}$ Yield, $0.43 \mathrm{~g}$ $(12 \%)$. IR $\left(\mathrm{CHCl}_{3}\right): 1655(\mathrm{C}=\mathrm{O}), 1610(\mathrm{C}=\mathrm{C}) \mathrm{cm}^{-1} \cdot{ }^{1} \mathrm{H}-\mathrm{NMR}\left(\mathrm{CCl}_{4}\right) \delta: 1.00\left(3 \mathrm{H}, \mathrm{t}, J=7 \mathrm{~Hz}, \mathrm{OCH}_{2} \mathrm{C}_{3}\right), 2.02(3 \mathrm{H}$, $\left.\mathrm{s}, \mathrm{C}_{6}-\mathrm{Me}\right), 2.35$ and $2.63\left(\right.$ each $\left.1 \mathrm{H}, \mathrm{d}, J=9 \mathrm{~Hz}, \mathrm{C}_{3}-\mathrm{H}_{2}\right), 3.23\left(2 \mathrm{H}, \mathrm{q}, J=7 \mathrm{~Hz}, \mathrm{OC}_{2} \mathrm{CH}_{3}\right), 5.30\left(1 \mathrm{H}, \mathrm{s}, \mathrm{C}_{5}-\mathrm{H}\right), 7.0-$ $7.6(5 \mathrm{H}, \mathrm{m}, \mathrm{Ph})$. MS $m / e: 232\left(\mathrm{M}^{+}\right)$. Further elution with ethyl acetate gave 15a. Yield, $0.64 \mathrm{~g}(23 \%)$.

Reaction of 1 with Butyl Vinyl Ether (13b)_A mixture of $1(4.26 \mathrm{~g})$ and $13 \mathrm{~b}(1.0 \mathrm{~g})$ was heated at $130^{\circ} \mathrm{C}$ for $30 \mathrm{~h}$. The reaction mixture was chromatographed on a silica gel $(60 \mathrm{~g})$ column. Elution with hexane-ethyl acetate (2:1) gave butyl acetoacetate $(0.8 \mathrm{~g})$. Further elution with ethyl acetate gave 2,6-dimethyl-3-(3-butoxypropenoyl)-4pyrone (16b) as an oil. Yield, $0.17 \mathrm{~g}(7 \%)$. Anal. Calcd for $\mathrm{C}_{14} \mathrm{H}_{18} \mathrm{O}_{4}: \mathrm{C}, 67.18 ; \mathrm{H}, 7.25$. Found: $\mathrm{C}, 66.99 ; \mathrm{H}, 7.22$. IR $\left(\mathrm{CHCl}_{3}\right): 1660(\mathrm{C}=\mathrm{O}), 1610(\mathrm{C}=\mathrm{C}) \mathrm{cm}^{-1} .{ }^{1} \mathrm{H}-\mathrm{NMR}\left(\mathrm{CDCl}_{3}\right) \delta: 0.7-2.0\left(7 \mathrm{H}, \mathrm{m}, \mathrm{C}_{3} \mathrm{H}_{7}\right), 2.25\left(3 \mathrm{H}, \mathrm{s}, \mathrm{C}_{6}-\mathrm{Me}\right), 2.30$ $\left(3 \mathrm{H}, \mathrm{s}, \mathrm{C}_{2}-\mathrm{Me}\right), 3.87\left(2 \mathrm{H}, \mathrm{t}, J=6 \mathrm{~Hz}, \mathrm{OCH}_{2}\right), 5.90(1 \mathrm{H}, \mathrm{d}, J=13 \mathrm{~Hz}, \mathrm{CH}=\mathrm{CHO}-), 6.10\left(1 \mathrm{H}, \mathrm{s}, \mathrm{C}_{5}-\mathrm{H}\right), 7.50(1 \mathrm{H}, \mathrm{d}$, $J=13 \mathrm{~Hz}, \mathrm{CH}=\mathrm{CHO}-)$, MS $m / e: 251\left(\mathrm{M}^{+}\right), 193,177,151$. Further elution with ethyl acetate gave 2-methyl-4-pyrone (15b) as an oil. Yield, $0.28 \mathrm{~g}(26 \%)$. The ${ }^{1} \mathrm{H}-\mathrm{NMR}$ data were identical with those given in the literature. ${ }^{22)}$

Reaction of 1 with 3,4-Dihydro-2 $\mathrm{H}$-pyran (13c) - A mixture of $1(5.68 \mathrm{~g})$ and $13 \mathrm{c}(1.68 \mathrm{~g})$ was heated at $130^{\circ} \mathrm{C}$ for $14 \mathrm{~h}$. The reaction mixture was concentrated in vacuo. The residue was chromatographed on a silica gel (70 g) column. Elution with ethyl acetate gave crystals. Recrystallization from ethyl acetate-hexane gave 3,4-dihydro- $2 \mathrm{H}$ pyran-5-yl 2,6-dimethyl-4-oxo-4H-pyran-3-yl ketone (16c) as needles of mp $153-155^{\circ} \mathrm{C}$. Anal. Calcd for $\mathrm{C}_{13} \mathrm{H}_{14} \mathrm{O}_{4}$ : C, 66.65; H, 6.02. Found: C, 66.41; H, 6.19. IR $\left(\mathrm{CHCl}_{3}\right): 1660(\mathrm{C}=\mathrm{O}), 1600(\mathrm{C}=\mathrm{C}) \mathrm{cm}^{-1} \cdot{ }^{1} \mathrm{H}-\mathrm{NMR}\left(\mathrm{CDCl}_{3}\right) \delta: 2.17$ $\left(3 \mathrm{H}, \mathrm{s}\right.$, pyran $\left.\mathrm{C}_{6}-\mathrm{Me}\right), 2.23\left(3 \mathrm{H}, \mathrm{s}\right.$, pyran $\left.\mathrm{C}_{2}-\mathrm{Me}\right), 1.60-2.57\left(4 \mathrm{H}, \mathrm{m}, \mathrm{C}_{2} \mathrm{CH}_{2} \mathrm{CH}_{2} \mathrm{O}\right), 4.13\left(2 \mathrm{H}, \mathrm{t}, \mathrm{J}=5 \mathrm{~Hz}, \mathrm{CH}_{2} \mathrm{O}\right)$, $6.08\left(1 \mathrm{H}, \mathrm{s}\right.$, pyran $\left.\mathrm{C}_{5}-\mathrm{H}\right), 7.35(1 \mathrm{H}, \mathrm{s},=\mathrm{CHO})$.

Reaction of 1 with Acetylacetone-A mixture of $1(8.52 \mathrm{~g})$ and acetylacetone $(3.0 \mathrm{~g})$ was heated at $120-130^{\circ} \mathrm{C}$ for $1 \mathrm{~h}$. The reaction mixture was distilled to give $0.93 \mathrm{~g}$ of acetylacetone. The residue was chromatographed on a silica gel $(140 \mathrm{~g})$ column. Elution with hexane-ethyl acetate $(4: 1)$ gave $1(1.62 \mathrm{~g})$. Successive elution with hexane-ethyl acetate $(2: 1)$ gave an oil, which on distillation afforded 2-acetonyl-2,4-dimethyl-1,3-dioxin-4(2H)-one (21) as an oil of bp $100{ }^{\circ} \mathrm{C}(0.001 \mathrm{mmHg})$. Yield, $0.67 \mathrm{~g}(12 \%)$. Anal. Calcd for $\mathrm{C}_{9} \mathrm{H}_{12} \mathrm{O}_{4}: \mathrm{C}, 58.69 ; \mathrm{H}, 6.57$. Found: $\mathrm{C}, 58.80 ; \mathrm{H}$, 6.74. IR $\left(\mathrm{CHCl}_{3}\right): 1710(\mathrm{C}=\mathrm{O}), 1630(\mathrm{C}=\mathrm{C}) \mathrm{cm}^{-1} .{ }^{1} \mathrm{H}-\mathrm{NMR}\left(\mathrm{CCl}_{4}\right) \delta: 1.72\left(3 \mathrm{H}, \mathrm{s}, \mathrm{C}_{2}-\mathrm{Me}\right), 2.00\left(3 \mathrm{H}, \mathrm{s}, \mathrm{C}_{6}-\mathrm{Me}\right)$, $2.18\left(3 \mathrm{H}, \mathrm{s}\right.$, acetyl), $3.02\left(2 \mathrm{H}, \mathrm{s}, \mathrm{CH}_{2}\right), 5.16\left(1 \mathrm{H}, \mathrm{s}, \mathrm{C}_{5}-\mathrm{H}\right)$. Further elution with hexane-ethyl acetate $(1: 1)$ gave $3-$ acetyl-2,6-dimethyl-4-pyrone $(\mathbf{2 0 a})$ as an oil of bp $85-92^{\circ} \mathrm{C}(0.3 \mathrm{mmHg})\left[\right.$ lit. $\left.^{8 a} \mathrm{bp} 100-105^{\circ} \mathrm{C}(3 \mathrm{mmHg})\right]$. Yield, $1.15 \mathrm{~g}(23 \%)$.

When the period of heating in this reaction was extended to $2 \mathrm{~h}$, only $20 \mathrm{a}$ was obtained. Yield, $3.12 \mathrm{~g}(63 \%)$.

Reaction of 1 with Benzoylacetone - A mixture of $1(8.52 \mathrm{~g})$ and benzoylacetone $(4.86 \mathrm{~g})$ was heated at 120 $130^{\circ} \mathrm{C}$ for $4 \mathrm{~h}$. The reaction mixture was chromatographed on a silica gel $(160 \mathrm{~g})$ column. Elution with hexane-ether $(9: 1)$ gave $2.22 \mathrm{~g}$ of benzoylacetone. Elution with hexane-ether $(3: 1)$ gave dehydroacetic acid $(0.49 \mathrm{~g})$. Elution with ether gave 3-benzoyl-2,6-dimethyl-4-pyrone (20b) as needles of $\mathrm{mp} 97-98^{\circ} \mathrm{C}$ (lit. $\left.{ }^{8 b}\right) \mathrm{mp} 97-98^{\circ} \mathrm{C}$ ) (recrystallized from ether-hexane). Yield, $2.36 \mathrm{~g}(36 \%)$.

Reaction of 1 with Cyclohexanone-A mixture of $1(2.84 \mathrm{~g})$ and cyclohexanone $(5.88 \mathrm{~g})$ was heated at $120^{\circ} \mathrm{C}$ for $1 \mathrm{~h}$. Distillation of the mixture gave 22 as an oil of bp $81{ }^{\circ} \mathrm{C}(0.1 \mathrm{mmHg})\left[l_{i t}{ }^{23)} \mathrm{bp} 117-122^{\circ} \mathrm{C}(0.4 \mathrm{mmHg})\right]$. Yield, $2.5 \lg (69 \%)$.

Acknowledgement The present work was supported in part by a Grant-in-Aid for Scientific Research from the Ministry of Education, Science and Culture, Japan, which is gratefully acknowledged. Thanks are due to Mrs. C. 
Koyanagi for elemental analyses, and to Miss E. Kurosawa for mass spectral measurements.

\section{References and Notes}

1) M. F. Carroll and A. R. Bader, J. Am. Chem. Soc., 74, 6305 (1952).

2) M. Sato, N. Kanuma, and T. Kato, Chem. Pharm. Bull., 30, 1315 (1982).

3) a) G. Jäger and J. Wenzelburger, Justus Liebigs Ann. Chem., 1976, 1689; b) M. Sato, H. Ogasawara, E. Yoshizumi, and T. Kato, Heterocycles, 17, 297 (1982); c) M. Sato, N. Kanuma, and T. Kato, Chem. Pharm. Bull., 30, 4359 (1982); d) M. Sato, H. Ogasawara, E. Yoshizumi, and T. Kato, Chem. Pharm. Bull., 31, 1902 (1983).

4) T. Kato, Acc. Chem. Res., 7, 265 (1976).

5) a) B. Milward, J. Chem. Soc., 1960, 26; b) S. Hünig, E. Benzing, and K. Hübner, Chem. Ber., 94,486 (1961).

6) a) E. Ziegler, I. Herbst, and Th. Kappe, Monatsh. Chem., 100, 132 (1969); b) T. Kato, H. Yamanaka, and T. Hozumi, Yakugaku Zasshi, 91, 740 (1971); c) P. Caramella and A. Querci, Synthesis, 1972, 42.

7) T. Kato, Y. Yamamoto, and S. Takeda, Chem. Pharm. Bull., 21, 1047 (1973).

8) a) K. Hamamoto, T. Isoshima, and M. Yoshioka, Nippon Kagaku Zasshi, 79, 840 (1958); b) T. Kato and T. Hozumi, Chem. Pharm. Bull., 20, 1574 (1972).

9) H. W. Moore and D. S. Wilbur, J. Org. Chem., 45, 4483 (1980).

10) A. Combes and C. Combes, Bull. Soc. Chim. Fr., 7, 779 (1892).

11) A. Michaelis, Justus Liebigs Ann. Chem., 1909, 337.

12) J. Moir, J. Chem. Soc., 81, 101 (1902).

13) C. Beyer and L. Claisen, Chem. Ber., 20, 2180 (1887).

14) S. Hünig, E. Benzing, and E. Lucke, Chem. Ber., 90, 2833 (1957).

15) S. M. McElvain and D. Kundiger, "Organic Syntheses," Coll. Vol. III, ed. by A. H. Blatt, John Wiley and Sons, Inc., New York, 1943, p. 506.

16) S. Kostancecki and J. Tambor, Chem. Ber., 32, 2263 (1899).

17) P. M. Walters and S. M. McElvain, J. Am. Chem. Soc., 62, 1482 (1940).

18) S. M. McElvain and C. L. Stevens, J. Am. Chem. Soc., 68, 1917 (1946).

19) Y. Ogata, A. Kawasaki, and K. Tsujimura, Tetrahedron, 27, 2765 (1971).

20) M. Rolla, M. Sanesi, and G. Traverso, Ann. Chim. (Roma), 44, 430 (1954).

21) Analytically pure 14 was not obtainable, since 14 partially decomposed during chromatography.

22) L. C. Dorman, J. Org. Chem., 32, 4105 (1967).

23) E. V. Dehmlow and A. R. Shamout, Justus Liebigs Ann. Chem., 1982, 1753. 